\title{
PERSEPSI MASYARAKAT TENTANG PENGGUNAAN FORMALIN DALAM BAHAN MAKANAN DAN PELAKSANAAN PENDIDIKAN GIZI DAN KEAMANAN PANGAN
}

\author{
Wiwi Wikanta \\ Pendidikan Biologi FKIP Universitas Muhammadiyah Surabaya \\ e-mail:wi2umsby@yahoo.co.id
}

\begin{abstract}
Formalin is not a preservative for foodstuffs and processed products. But until recently, the use of formaldehyde in foodstuffs is still common. Whereas, nutrition and food security education for the community is still lacking. This study aimed to: (a) obtaining community about the use of formaldehyde in foodstuffs views of knowledge, attitude and behavior, and (2) obtaining community about the implementation of nutrition and food security education. Research using a sample survey method Sidoarjo urban communities with accidental sampling technique. Data collected by questionnaire and analyzed descriptively. The results showed that (1) almost all respondents knew there was food berformalin (90.91\%); (2) examine the impact hazard (87.88\%); (3) most feel uneasy (75.76\%) and fear dangers affected $(96.97 \%)$; (4) almost all respondents agreed formalin banned as a food preservative (90.91\%), (5) most respondents $(72.73 \%)$ has not made efforts to eliminate the formaldehyde in foodstuffs, and (6) almost all respondents (85.86\%) Mersa not get enough nutrition education and food security. Conclusion: The public assumes that (1) the use of formalin in the food injurious to health and safety of consumers, (2) people need nutrition and food safety education are adequate.
\end{abstract}

Kata Kunci: persepsi, formalin, bahan makanan, pendidikan, gizi dan keamanan pangan

Makanan merupakan salah satu kebutuhan pokok hidup manusia, karena dari makanan manusia mendapatkan zatzat gizi yang dibutuhkan tubuh. Zat gizi dibutuhkan tubuh untuk pertumbuhan, mempertahankan dan memperbaiki jaringan tubuh, mengatur proses dalam tubuh, dan menyediakan energi bagi fungsi tubuh (Muchtadi, 2010). Bahan makanan yang dibutuhkan tubuh adalah bahan makanan yang sehat dan aman.

Sehat dalam pengertian, bahan makanan dapat memenuhi jenis dan jumlah zat gizi yang sesuai dengan kebutuhan tubuh. Zat gizi yang harus ada dalam bahan makanan agar tubuh sehat, meliputi golongan protein, lemak, dan karbohidrat yang disebut zat gizi makro; serta vitamin dan mineral yang disebut zat gizi mikro (Haris dan Karmas (Eds.), 1989; Linder, 1992). Sedangkan, aman

artinya bahan makanan yang dikonsumsi harus bebas dari bahan racun dan berbahaya yang dapat membahayakan kesehatan atau keselamatan manusia (BPOM, 2003). Keamanan makanan atau pangan menurut Undang-undang RI No. 7 tahun 1996 tentang Pangan adalah kondisi dan upaya yang diperlukan untuk mencegah pangan dari kemungkinan cemaran biologis, kimia, dan benda lain yang dapat mengganggu, merugikan dan membahayakan kesehatan manusia (Pemerintah RI, 1996).

Pada umumnya, bahan makanan berasal dari komoditas pertanian, perikanan dan perkebunan yang rentan mengalami kerusakan dan pembusukan. Kerusakan yang terjadi sering disertai dengan pembentukan senyawa beracun, disamping hilangnya nilai zat gizi bahan 
pangan (Desrosier, 2008). Oleh karena itu, bahan makanan harus segera diolah setelah panen.

Pengawetan dan memasak merupakan dua macam pengolahan bahan makanan yang sering dilakukan oleh masyarakat. Pengawetan pada hakikatnya adalah merupakan salah satu usaha untuk menekan, mengurangi atau menghalangi mikroba yang tergolong pathogen dan penghasil racun pada bahan makanan (Supardi dan Sukamto, 1999). Sedangkan, memasak merupakan cara pengolahan agar bahan makanan dapat diterima secara sensori, baik dari penampilan (aroma dan rasa) maupun teksturnya (kekerasan, kelembutan, konsistensi, kekenyalan, kerenyahan) (Apriyantono, 2002).

Namun, pada kenyataan menunjukkan bahwa pengolahan tidak selalu menghasilkan keuntungan sesuai yang diinginkan, yaitu aman, bergizi dan dapat diterima dengan baik secara sensori sering kali, pengolahan dapat menimbulkan hal yang sebaliknya, yaitu menghasilkan senyawa toksik sehingga produk menjadi kurang atau tidak aman, kehilangan zat gizi dan perubahan sifat sensori kea rah yang tidak dinginkan (Apriyantono, 2002). Apalagi, pengawetan bahan makanan dilakukan dengan proses dan penggunaan bahan tambahan yang tidak sesuai dengan aturan yang berlaku (Cahyadi, 2008). Kasus formalin dalam bahan makanan, merupakan salah satu contoh dari sekian banyak penyalahgunaan bahan tambahan yang tidak sesuai dengan peraturan.

Sampai saat ini, penggunaan formalin dalam bahan makanan masih marak dilakukan para produsen yang tidak bertanggung jawab. Bukti menunjukkan bahwa banyak bahan makanan yang mengandung formalin beredar di beberapa pasar, seperti Malang, Medan, Palu, Depok, dan
Sidoarjo (Innamasari, 2007; Karo-karo, Trijaya dan Fit, 2008; Darlis, 2009; Virdhani, 2009; Surabayapost, 2009; Jawa Pos, 2009). Padahal, Pemerintah RI melalui Menteri Kesehatan dengan Permenkes RI No. 722/MENKES/PER/IX/1988 dan No. 1168/MENKES/PER/X/1999, telah menetapkan bahwa formalin merupakan bahan pengawet yang dilarang untuk bahan makanan dan olahannya.

Formalin, yang tidak lain larutan formaldehid dalam air, merupakan bahan pengawet yang membahayakan kesehatan dan keselamatan manusia. Beberapa hasil penelitian menujukkan bahwa formalin atau formaldehid dapat menyebabkan dampak akut, seperti iritasi dan kronik sebagai karsinogen (Hove and Lohrey, 1976; Ritchie and Lehnen, 1987; Shaham et al., 1996; Naria, 2004; Zahra, Parviz, Simin, dan Mehdi, 2007; Nolodewo, Yuslam, dan Muyassaroh. 2007; Santy, 2007; Innamasari, 2007; Susanti, 2007; Kurnia, 2007; Kartikaningsih, 2008).

Di sisi lain, ancaman bahaya formalin dalam bahan makanan diperparah oleh rendahnya pengetahuan masyarakat dalam mengolah bahan makanan (Mulia, 2007). Kebiasaan masyarakat dalam memasak, belum beroritentasi pada nilai gizi dan keamanan bahan makanan. Pada umumnya, masyarakat memasak bahan makanan lebih berorientasi pada cita rasa dan tampilan bahan makanan, sehingga aspek utama menyediakan bahan makanan sehat dan aman terabaikan. Pengetahuan masyarakat dalam memasak bahan makanan masih terbatas. Sedangkan, keracunan makanan, diantaranya disebabkan oleh karena kelalaian dan ketidaktahuan masyarakat dalam pengolahan bahan makanan (Rafif, 2010).

$\begin{array}{cc}\text { Selama } & \text { ini, masyarakat } \\ \text { memperoleh } & \text { pengetahuan tentang }\end{array}$


memasak dari keluarga yang diturunkan dari generasi ke generasi atau pengalaman pribadi (Hartono, 2006). Kondisi pengetahuan masyarakat seperti ini dapat membahayakan keselamatan masyarakat sendiri. Pada dasarnya, pendidikan merupakan salah satu faktor penyebab gizi buruk pada masyarakat (Mardiyansyah, 2008). Oleh karena itu, masyarakat perlu mendapat pendidikan tentang gizi dan keamanan pangan yang memadai dari pihak terkait.

Tanggapan masyarakat terhadap kasus bahan makanan berformalin belum banyak terungkap. Selain itu, keadaan pengetahuan masyarakat tentang gizi dan keamanan pangan juga masih sedikit data yang tersedia. Oleh karena itu, perlu ada penelitian yang representatif tentang tanggapan (persepsi) masyarakat terhadap masalah bahan makanan berformalin dan pelaksanaan pendidikan gizi dan keamanan pangan ini. Penelitian ini dilakukan untuk: (1) mendeskripsikan tanggapan masyarakat tentang penggunaan formalin dalam bahan makanan; (2) mendeskripsikan tanggapan masyarakat tentang pelaksanaan pendidikan gizi dan keamanan pangan.

\section{METODE}

Penelitian ini merupakan penelitian deskriptif dengan menggunakan metode survei terbatas. Variabel penelitian adalah persepsi masyarakat ditinjau dari aspek pengetahuan (kognisi), perasaan (afeksi), dan tindakan (konasi) tentang penggunaan formalin dalam bahan makanan dan pelaksanaan pendidikan gizi dan keamanan pangan.

Sampel dalam penelitian ini diambil dari masyarakat Kabupaten Sidoarjo yang berdomisili di perkotaan dengan teknik sampling kebetulan (accidental sampling) (Prijana dan Semendison, 2005). Ada pun pertimbangan penentuan kelompok masyarakat perkotaan adalah masyarakat yang memiliki rantai terpanjang dalam distribusi bahan makanan dari sumbernya.

Pengumpulan data menggunakan intrumen angket yang disebarkan secara langsung kepada anggota keluarga yang kebetulan ada pada saat itu. Data selanjutnya diolah secara deskriptif.

\section{HASIL}

Dari hasil penelitian diperoleh data yang meliputi: (1) gambaran umum responden; (2) persepsi masyarakat tentang penggunaan formalin dalam bahan makanan (kognisi, konasi dan afeksi); dan (3) persepsi masyarakat tentang pelaksanaan pendidikan gizi dan keamanan pangan.

\section{Gambaran Umum Responden}

Responden yang berhasil disurvei dalam penelitian ini sebanyak 33 kepala keluarga yang tersebar pada 4 desa dari dua kecamatan kota. Data responden yang dikumpulkan meliputi: umur, jenis kelamin, pendidikan, dan pekerjaan. Secara lengkap gambaran data responden disajikan dalam Tabel 1. 
Tabel 1. Distribusi Responden berdasarkan Umur, Jenis Kelamin, Pendidikan dan Pekerjaan di Kab. Sidoarjo

\begin{tabular}{|c|c|c|}
\hline Ciri Responden & $\begin{array}{l}\text { Jumlah } \\
\text { (orang) }\end{array}$ & Persentase $(\%)$ \\
\hline \multicolumn{3}{|l|}{ Umur: } \\
\hline$<20$ & 4 & 12,12 \\
\hline $21-30$ & 6 & 18,18 \\
\hline $31-40$ & 13 & 39,40 \\
\hline $41-50$ & 8 & 24,24 \\
\hline$>50$ & 2 & 06,06 \\
\hline Jumlah & 33 & 100 \\
\hline \multicolumn{3}{|l|}{ Jenis kelamin } \\
\hline Laki-laki & 10 & 30,30 \\
\hline Perempuan & 23 & 69,70 \\
\hline Jumlah & 33 & 100 \\
\hline \multicolumn{3}{|l|}{ Pendidikan } \\
\hline Tidak Sekolah & 1 & 3,03 \\
\hline SD & 0 & 0,00 \\
\hline SMP & 5 & 15,15 \\
\hline SMA & 19 & 57,57 \\
\hline Diploma (D1/D2/D3) & 3 & 9,10 \\
\hline Sarjana (S1) & 5 & 15,15 \\
\hline Pascasarjana (S2/S3) & 0 & 0,00 \\
\hline Jumlah & 33 & 100 \\
\hline \multicolumn{3}{|l|}{ Pekerjaan } \\
\hline Ibu Rumah Tangga & 9 & 27,27 \\
\hline Guru/Dosen & 4 & 12,12 \\
\hline Karyawan/Swasta & 13 & 39,40 \\
\hline $\begin{array}{l}\text { Tidak } \\
\text { Bekerja/Pensiun/Lain }\end{array}$ & 7 & 21,21 \\
\hline Jumlah & 33 & 100 \\
\hline
\end{tabular}

Dari Tabel 1 di atas, pada umumnya umur responden terdistribusi hampir merata pada semua kelompok umur. Sedangkan, responden terbanyak dalam penelitian ini berada pada kelompok umur 31 - 40 tahun $(39,40 \%)$ dan responden paling kecil pada kelompok umur > 50 tahun $(6,06 \%)$. Responden sebagian besar adalah perempuan $(69,70 \%)$ dengan pekerjaan sekitar 27,27\% sebagai ibu rumah tangga. Tingkat pendidikan responden didominasi lebih dari separuh $(57,57 \%)$ adalah lulusan SMA.

\section{Persepsi Masyarakat tentang Penggunaan Formalin dalam Bahan Makanan}

Pengetahuan Masyarakat tentang Penggunaan Formalin dalam Bahan
Makanan. Gambar 1, menunjukkan data pengetahuan masyarakat yang menggambarkan persepsi tentang penggunaan formalin dalam bahan makanan.

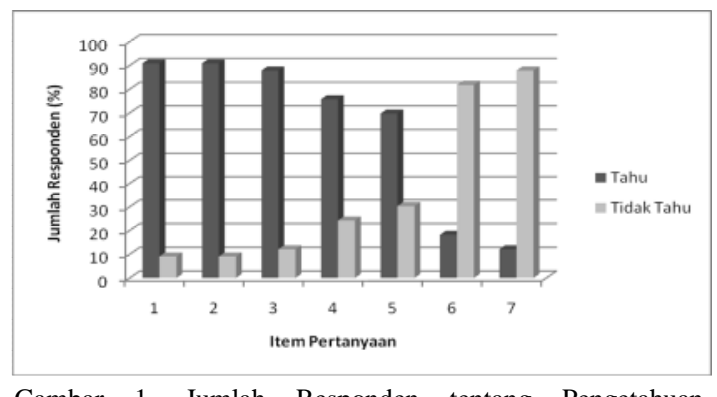

Gambar 1. Jumlah Responden tentang Pengetahuan Masyarakat terhadap Penggunaan Formalin dalam Bahan Makanan. Grafik: $1=$ pemberitaan bahan makanan berformalin; 2 = keguanaan formalin; 3 = dampak formalin terhadap kesehatan; 4 = dampak formalin terhadap zat gizi; 5 $=$ ciri-ciri bahan makanan berformalin; $6=$ cara menghilangkan formalin dalam bahan makanan; belimbing wuluh sebagai bahan deformalinisasi. 
Dari hasil survei menunjukkan bahwa responden secara umum $(90,91 \%)$ telah mengetahui kasus bahan makanan berformalin. Sekitar 63,64\% responden telah mengetahui kasus makanan berformalin lebih dari satu tahun. Pada umumnya, masyarakat memperoleh informasi dari pemberitaan, terutama siaran televisi $(75,75 \%)$.

Hampir seluruh responden telah mengetahui, baik penggunaan maupun dampak bahaya formalin. Sekitar 90,91\% responden mengetahui bahwa formalin bukan pengawet untuk bahan makanan. Sedangkan, lebih dari $75 \%$ responden mengetahui dampak bahaya formalin, baik terhadap kesehatan maupun zat gizi bahan makanan.

Berdasarkan hasil survei diperoleh data bahwa masih banyak responden, sekitar 30\%, yang belum mengetahui ciri-ciri bahan makanan berformalin. Sedangkan, sebagian besar $(81,82 \%)$ responden belum mengetahui cara menghilangkan formalin dalam bahan makanan.

\section{Sikap tentang Penggunaan Formalin} dalam Bahan Makanan. Gambar 2, menunjukkan bahwa penggunaan formalin dalam bahan makanan telah meresahkan sebagian besar masyarakat. Sekitar $75,76 \%$ responden menyatakan sikap bahwa keberadaan bahan makana berformalin telah meresahkan masyarakat . Hampir seluruh responden $(96,97 \%)$ merasa takut terkena dampak bahaya formalin. Hampir seluruh responden $(93,94 \%)$ setuju bahwa bahan makanan berformalin dapat membahayakan kesehatan dan keselamatan masyarakat. Sedangkan, hampir semua responden setuju $(90,91 \%)$ bahwa formalin tidak boleh dipergunaan sebagai pengawet bahan makanan. Sedangkan, lebih separuh responden setuju $(66,67 \%)$ perlu adanya hukuman bagi pelanggar.

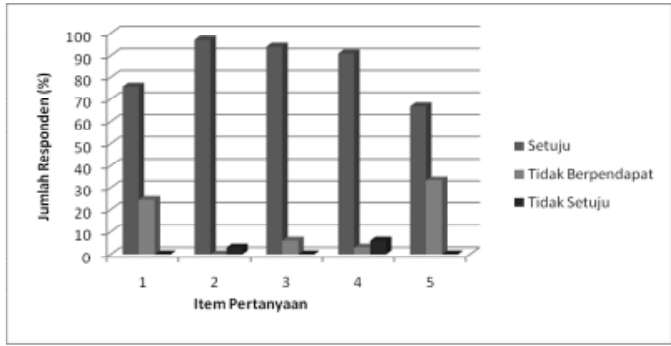

Gambar 2. Jumlah Responden tentang Sikap Masyarakat terhadap Penggunaan Formalin dalam Bahan Makanan. Grafik: $1=$ bahan makanan berformalin membuat resah; 2 = bahan makanan berformalin membuat takut; $3=$ bahan makanan berformalin membahayakan kesehatan; $4=$ formalin bukan pengawet bahan makanan; $5=$ pengguna formalin dalam bahan makanan perlu dihukum.

\section{Perilaku Masyarakat tentang} Penggunaan Formalin dalam Bahan Makanan. Gambar 3, menujukkan data perilaku masyarakat tentang cara membeli bahan makanan di pasar. Kurang dari separuh responden $(42.42 \%)$ yang selalu memilih dan meneliti bahan makanan yang akan dibeli di pasar dan hanya segian kecil responden (12.12\%) yang tidak Meneliti/memilih bahan makanan yang akan dibeli.

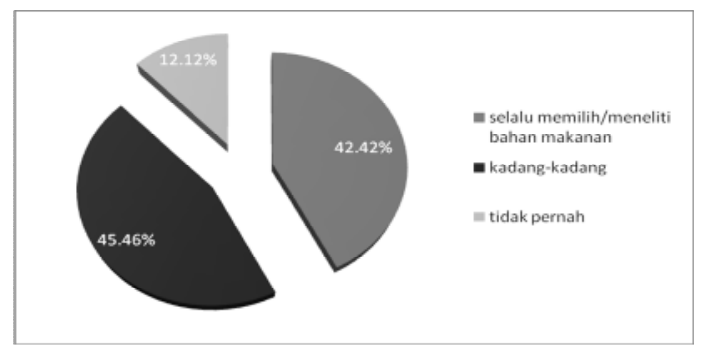

Gambar 3. Perilaku Masyarakat tentang Cara Membeli Bahan Makanan di Pasar

Gambar 4, menunjukkan perilaku responden dalam menghindari bahaya bahan makanan berformalin. Dimana, lebih dari separuh responden (54.55\%) masih membeli bahan makanan yang diberitakan berformalin. Sebagian besar responden $(72,73 \%)$ tidak melalukan upaya menghilangkan formalin dalam bahan makanan selama pengolahan dan lebih separuh responden $(51,52 \%)$ tidak pernah memberitahukan informasi tentang ciri-ciri bahan 
makanan berformalin tetangga atau orang lain.

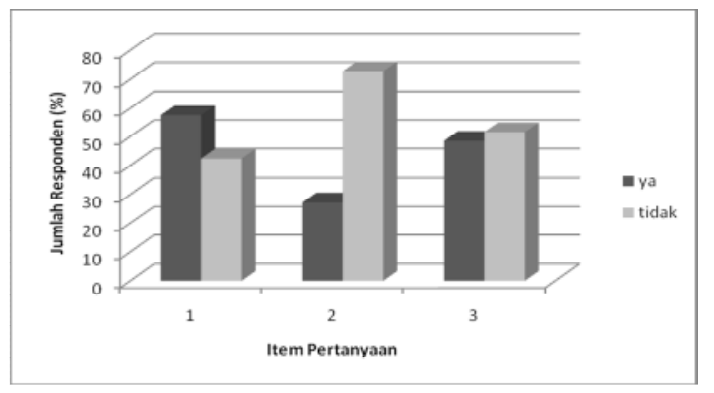

Gambar 4. Perilaku Responden dalam Menghindari Bahaya Bahan Makanan Berformalin. Grafik: $1=$ membeli bahan makanan berformalin; $2=$ usaha menghilangkan formalin; 3 = memberitahu cirri-ciri bahan makanan berformalin

Gambar 5, menunjukkan perilaku responden dalam pengolahan bahan makanan. Lebih dari separuh responden $(54,55 \%)$ hanya mencuci dan memasak langsung bahan makanan yang dibeli dari pasar dan sebagian kecil responden melakukan tindakan lain, seperti merendam dalam iar panas, air garam dan air cuka.

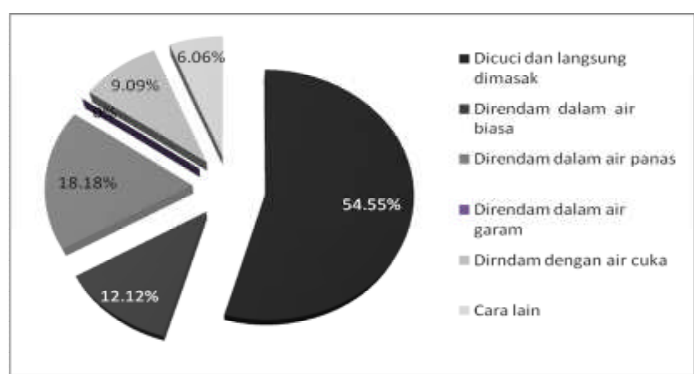

Gambar 5. Perilaku responden dalam Mengolah Bahan Makanan

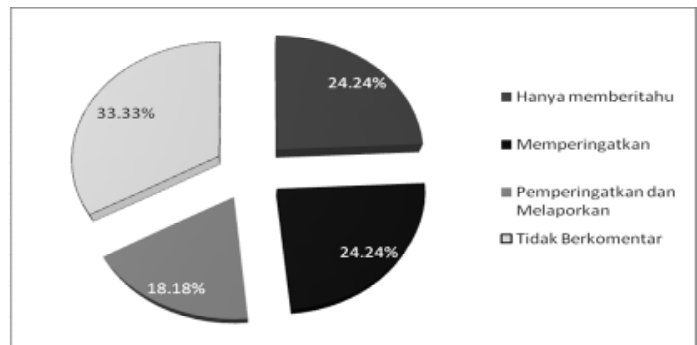

Gambar 6. Perilaku responden dalam Memberi Hukuman kepada Pedagang Bahan Makanan Berformalin
Gambar 6, menunjukkan data perilaku responden dalam memberihukuman kepada pedagang bahan makanan berformalin. Sekitar $33,33 \%$ responden membiarkan para pedagang yang menggunakan formalin dalam bahan makanan dan hanya $18,18 \%$ yang memberi peringatan dan melaporkan ke petugas terkait. Sedangkan, sebagian besar responden $(33,33 \%)$ tidak berkomentar.

\section{Persepsi Masyarakat tentang Pelaksanaan Pendidikan Gizi Dan Keamanan Pangan}

Gambar 7, menunjukan sikap responden tentang penggunaan formalin dalam bahan makanan sebagai kurangnya pendidikan gizi dan keamanan pangan untuk masyarakat.

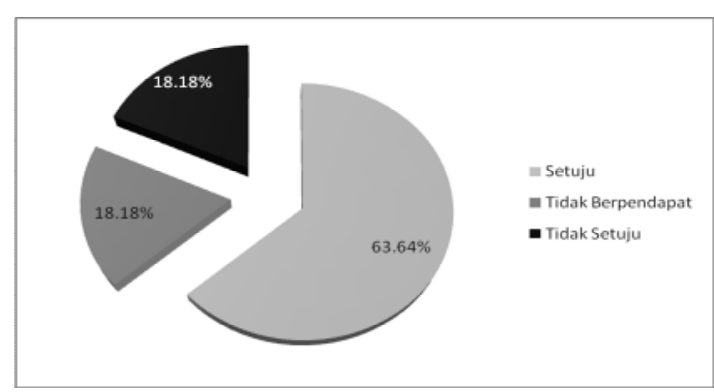

Gambar 7. Sikap Responden tentang Penggunaan Formalin dalam Bahan Makanan sebagai Kuranngnya Pendidikan Gizi dan Kemanan Pangan

Dari gambar di atas, responden memandang bahwa pendidikan gizi dan keamanan pangan masih kurang. Lebih dari separuh responden $(63,64 \%)$ menyatakan setuju bahwa penyalahgunaan formalin dalam bahan makanan sebagai akibat kurangnya pendidikan gizi dan keamanan pangan kepada masyarakat.

Gambar 8, menunjukkan pengetahuan pendidikan gizi dan keamanan pangan yang dimiliki responden. Lebih dari separuh responden $(60,60 \%)$ menyatakan tidak pernah 
mendapat pendidikan khusus tentang pendidikan gizi dan keamanan pangan. Hampir seluruh responden $(84,85 \%)$ menyatakan bahwa bentuk penyajian materi pendidikan gizi dan keamanan pangan yang selama ini tersedia belum menarik dan belum terjangkau dan Hampir seluruh responden $(84,85 \%)$ selama ini merasa belum cukup mendapat pengetahuan tentang gizi dan keamanan pangan.

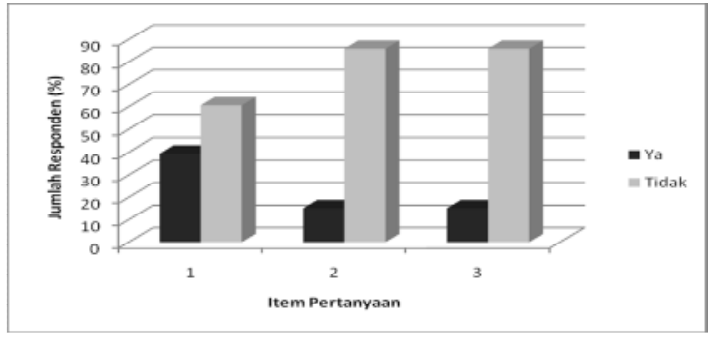

Gambar 8. Pengetahuan Gizi dan Keamanan Pangan Masyarakat. Grafik: 1 = pendidikan gizi yang pernah diperoleh; 2 = penyajian materi pendidikan gizi; 3 = pengtahuan yang sudah dimiliki.
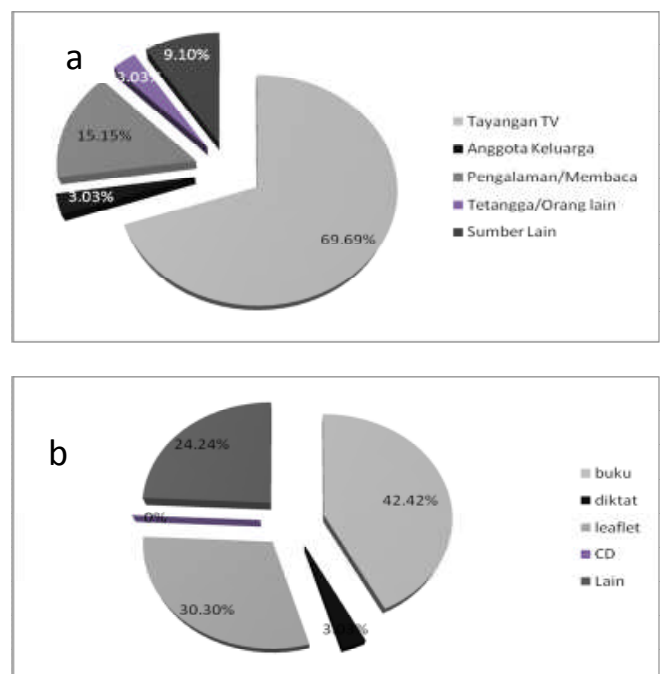

Gambar 9. Sumber Pengetahuan Gizi dan Keamanan Pangan. Gambar: $\mathrm{a}=$ sumber pengetahuan; $\mathrm{b}=$ bentuk kemasan materi.

Selama ini, lebih dari separuh responden $(69,69 \%) \quad$ mendapat pengetahuan tentang gizi dan keamanan pangan dari televisi (Gambar 9a). Bentuk penyajian materi pendidikan gizi dan keamanan pangan menurut sebagian besar responden $(42,42 \%)$ adalah dalam bentuk buku (Gambar 9b).

Harapan responden tentang pelaksanaan pendidikan gizi dan keamanan pangan terungkap bahwa hampir seluruhnya mengharapkan adanya program yang ditetapkan pemerintah setempat $(87,88 \%)$; dilakukan rutin dan terjadwal $(33,33 \%)$, disampaikan oleh tenaga ahli $(36,36 \%)$, penyajian materi yang menarik dan terjangkau $(30,30 \%)$, dan dilaksanakan untuk masyarakat secara cuma-cuma atau tanpa dipungut biaya $(45,45 \%)$.

\section{PEMBAHASAN}

Kabupaten Sidoarjo merupakan salah satu pemerintahan daerah di Jawa Timur yang berbatasan langsung dengan Kota Metropolis Surabaya. Kabupaten dengan luas wilayah sekitar 63.438.543 ha atau $634,39 \mathrm{~km}^{2}$ terdiri atas 18 kecamatan dan 353 desa yang tersebar pada empat wilayah. Sidoarjo merupakan daerah penghasil perikanan terbesar di Jawa Timur (Adika, tanpa tahun).

Kasus bahan makanan berformalin, bukan masalah baru. Sejak akhir tahun 2005, kasus bahan makanan berformalin sudah banyak dibicarakan dalam berbagai forum, baik ilmiah maupun non ilmiah (AAK UMSurabaya, 2005). Sejalan dengan waktu, kasus bahan makanan berformalin terus bergulir dan berita pun silih berganti melaporkan hasil temuan bahan makanan berformalin yang beredar di pasaran (Karo-karo, Trijaya dan Fit, 2008; Darlis, 2009; Virdhani, 2009; Surabayapost, 2009; Jawa Pos, 2009). Dengan demikian, informasi kasus bahan makanan berformalin mudah diperoleh oleh masyarakat, terutama masyarakat perkotaan melalui media televisi.

Secara akut, formaldehid atau formalin dapat menyebabkan iritasi pada 
saluran pernapasan dan pencernaan, ruam kulit, mual dan muntah (Ritchie and Lehnen, 1987; Naria, 2004). Sedangkan, dampak kronis formaldehid atau formalin dapat menyebabkan kerusakan beberapa organ dalam, seperti usus, hati, dan ginjal, yang mengarah kepada kanker (Shaham et al., 1996; Zahra, Parviz, Simin, dan Mehdi, 2007; Nolodewo, Yuslam, dan Muyassaroh. 2007; Santy, 2007; Innamasari, 2007; Susanti, 2007; Kurnia, 2007; Kartikaningsih, 2008; Mahdi, 2008).

Selain, dampak langsung terhadap tubuh, formalin juga dapat menyebabkan dampak buruk terhadap zat gizi bahan makanan. Formalin dapat menyebabkan kerusakan dan penurunan nilai gizi bahan makanan, terutama protein. Hove and Lohrey (1976) mengemukakan bahwa perlakuan formaldehid dapat menurunkan nilai gizi casein pakan mencit. Sihombing dan Sihombing (1996) mengemukakan hal serupa bahwa tahu yang direndam dalam formalin menyebabkan tekstur yang keras dan kaku, nilai diet dan PER yang terus menurun sejajar dengan bertambahnya konsentrasi formalin, serta merusak protein sehingga menurunkan nilai gizi tahu sebagai sumber protein. Penggunaan zat aditif (tambahan) dalam makanan dan minuman sangat berbahaya bagi kesehatan masyaratkan, terutama zat tambahan bahan kimia sintetis yang toksik dan berakumulasi dalam tubuh untuk jangka waktu yang relatif lama bagi yang menggunakannya (Rafif, 2010).

Pengetahuan mengenal ciri-ciri bahan manakan berformalin sangat penting. Hal ini, menurut Widyaningsih dan Murtini (2006) merupakan langkah awal, paling mudah dan murah mencegah dampak bahaya formalin. Tindakan masyarakat tidak mengkonsumsi bahan makanan yang diberitakan mengandung formalin, bukan cara yang bijaksana dalam menghindari bahaya formalin. Jika, hal tersebut dilakukan, maka masyarakat akan terancam gizi kurang dan gizi buruk. Upaya lain yang dapat dilakukan masyarakat untuk menghindari bahaya formalin dalam bahan makanan adalah dengan cara menghilangkan atau mengurangi kandungan formalin dalam bahan makanan. Raihan (2003) mengemukakan bahwa kadar formalin dalam bahan makanan dapat dikurangi dengan beberapa perlakuan, di antaranya: (1) merendam dengan air; (2) merendam dengan air leri; dan (3) merendam dengan air garam. Hasil penurunan kadar formalin menunjukkan bahwa perendaman dalam air garam selama 60 menit dapat mencapai $90,61 \%$.

Keresahan dan ketakukan masyarakat mengkonsumsi bahan makanan berformalin berdampak terhadap daya beli dan konsumsi bahan makanan (Widodo dan Rudimah, tanpa tahun). Padahal, bahan makanan yang sering diberitakan mengandung formalin merupakan bahan makanan utama yang biasa dikonsumsi masyarakat, sehingga akan mengancam kecukupan gizi bagi tubuh.

Fenomena perilaku masyarakat berdasarkan data hasil penelitian ini, kurang relevan, baik dengan pengetahuan maupun dengan sikap. Faktor inilah yang menyebabkan dua hal penting dalam penyalahgunaan formalin dalam bahan makanan, yaitu: (1) ancaman bahaya formalin terhadap kesehatan dan keselamatan masyarakat tetap tinggi dan (2) penggunaan formalin dalam bahan makanan yang beredar di pasaran tetap marak. Oleh karena itu, perlu adanya upaya meningkatkan pengetahuan masyarakat tentang pengolahan bahan makanan.

Rendahnya tindakan yang harus dilakukan masyarakat dalam mengatasi bahan berbahaya dalam bahan makanan 
menunjukkan masih kurangnya pengetahuan masyarakat tentang pengolahan bahan makanan. Proses pengolahan bahan makanan yang dilakukan masyarakat masih bersifat rutinitas. Proses pengolahan bahan makanan yang dilakukan masyarakat belum berorientasi pada gizi dan keamanan. Apriyantono (2002) mengemukakan bahwa ada dua hal penting yang perlu dipertimbangkan dalam pengolahan pangan, yaitu (1) untuk mendapat bahan pangan yang aman untuk dimakan sehingga nilai zat gizi yang dikandung bahan pangan dapat dimanfaatkan secara maksimal dan (2) bahan pangan dapat diterima, khususnya secara sensoris, yang meliputi penanmpakan (aroma, rasa, mouthfeel) dan tektur (kekerasan, kelembutan, konsistensi, kekenyalan, kerenyahan).

Penggunaan formalin dalam bahan makanan sudah seharusnya dihentikan. Penggunaan formalin dalam bahan makanan, selain merugikan kepada konsumen, juga merugikan kepada pedang. Widodo dan Rudimah (tanpa tahun) mengemukakan bahwa pemberitaan penggunaan formalin menurunkan keyakinan konsumen terhadap keamanan pangan, mengurangi kecenderungan mengkonsumsi, meningkatkan selektivitas tempat pembelian, dan menurunkan intensitas pembelian.

Penegakkan hukum bagi pelanggar penggunaan formalin dalam bahan makanan masih lemah. Penegakkan hukum seperti ini yang menyebabkan masih maraknya penggunaan formalin dalam bahan makanan, terutama pada komoditas hasil laut atau perikanan. Sebenarnya, larangan penggunaan formalin dalam bahan makanan telah diatur oleh badan internasional maupun oleh Departemen Kesehatan, seperti UU No. 7 tahun 1996 tentang Pangan, UU No. 8 tahun 1999 tentang perlindungan konsumen, distorsi penggunaan formalin secara sengaja dalam produk makanan dapat diancam pidana penjara maksimal lima tahun atau denda maksimal Rp. 600 juta (Prijono, 2007). Namun, penggunaan formalin dalam bahan makanan laut, berhubungan dengan banyak faktor, salah satunya adalah kondisi ekonomi masyarakat nelayan. Pada umumnya, masyarakat nelayan termasuk golongan ekonomi lemah. Sedangkan, biaya sekali melaut sangat tinggi, sehingga para nelayan terpaksa menggunakan formalin sebagai pengawet hasil tangkapan untuk mengurangi biaya pembelian es (Kompas Cyber Media, 2009).

Kurangnya pendidikan gizi dan keamanan pangan, merupakan salah satu faktor penyebab tingginya kasus gizi buruk. Kasus gizi buruk yang muncul akhir-akhir ini, tahun 2005, di beberapa daerah Indonesia, merupakan sisi lain dari permasalahan gizi terkait dengan rendahnya pengetahuan dan keterampialan masyarakat memilih dan mengolah bahan makanan. Siti Fadilah, Menteri Kesehatan RI dalam Mardiyansyah (2008) mengemukakan bahwa ada tiga hal yang menyebabkan terjadinya gizi buruk, yaitu kemiskinan, pendidikan rendah, dan kesempatan kerja rendah. Ketiga hal itu, dipandang sebagai penyebab kekurangnya ketersediaan pangan, pola asuh anak keliru, kurangnya asupan gizi, dan terkena infeksi penyakit. Selain itu, Taslim (2005) menemukan fakta bahwa masih rendahnya penyuluhan yang dilakukan posyandu, hanya $22 \%$, dan hanya $13 \%$ ibu balita yang mengerti pembacaan KMS.

Sedikitnya ada 4 hal penting yang diperoleh dari pendidikan bagi masyarakat dan pengolah makanan, baik yang domestik maupun professional mengenai cara-cara menyiapkan makanan yang aman (Hartono, 2006), 
yaitu: (1) menjamin agar makanan tidak terkontaminasi oleh mereka sendiri; (2) agar kontaminan yang mungkin ada dalam bahan pangan dapat dihilangkan atau dikurangi sampai ke tingkat yang aman; (3) agar pertumbuhan mikroorganisme sampai mencapai tingkat yang menimbulkan penyakit, ataupun menghasilkan toksin, dapat dicegah; (4) agar makanan terkontaminasi yang tidak bisa dianggap aman dapat dihindari.

\section{KESIMPULAN DAN SARAN}

\section{Kesimpulan}

Dari hasil penelitian ini dapat disimpulkan bahwa masyarakat telah mengetahui kasus bahan makanan berformalin dan menolak penggunaannya dalam bahan makanan. Namun, masyarakat belum melakukan usaha tindakkan pencegahan dampak bahaya formalin dalam bahan makanan. Masyarakat menganggap bahwa pendidikan gizi dan keamanan pangan belum memadai dan perlu adanya peningkatan, baik program maupun pelaksanaannya.

\section{Saran}

Saran dari hasil penelitian ini, sebaiknya masyarakat dengan penegak hukum dan petugas kesehatan bekerja sama dalam menghentikan produsen/pedagang bahan makanan menggunakan formalin. Pemerintah daerah bekerja sama dengan dinas kesehatan dan perguruan tinggi untuk melakukan pendidikan gizi dan keamanan pangan secara terprogram dan terjadwal secara cuma-cuma. Perlu adanya penelitian lanjutan tentang upaya pencegahan dampak bahaya formalin dalam bahan makanan.

\section{DAFTAR RUJUKAN}

Adika, I Nyoman. Tanpa tahun. Pengembangan Wilayah Kabupaten Sidoarjo sebagai Wilayah Pinggiran Kota Metropilis Surabaya dan Mobilitas Penduduk. (Online). (http://www.akademik.unsuri.ac.id. Diakses 13 November 2009).

Apriyantono, Anton. 2002. Pengaruh Pengolahan terhadap Nilai Gizi dan Keamanan Pangan. Makalah disampaikan pada Seminar Online Kharisma ke-2. 16-22 Desember $2002 . \quad$ Dunia Maya. (http://www.pdf-search-engine.com. Diakses 2 Oktober 2009).

Cahyadi, Wisnu. 2008. Analisis dan Aspek Kesehatan Bahan Tambahan Pangan. Jakarta: Bumi Aksara.

Darlis, 2009. BPOM Palu Perikasa Ikan Berformalin. (Online). (http://www.tempointeraktif.com. Diakses 13 November 2009).

Desrosier, Norman W. 2008. Teknologi Pengawetan Pangan. Ed. Ke-3. Penerjemah: Muchji Miljohardjo. Jakarta: UI-Press

Harris, Robert S. dan Karmas, Endel. (Eds). 1989. Evaluasi Gizi pada Pengolahan Bahan Makanan. Penerjemah: Suminar Achmadi. Bandung: ITB.

Hartono, Andry. 2006. Penyakit Bawaan Makanan: Fokus Pendidikan Kesehatan. Jakarta: EGC.

Hove, Edwin L. and Lohrey, Evelyn. 1976. The Effect of Formaldehyde on the Nutritive Value of Casein and Lactalbumin in the Diet of Rats. J.Nutr., 106: 382-387.

Innamasari, Diayah. 2007. Pengaruh Konsumsi Ikani Asin Kuniran (Ipeneus sulphureus) Berformalin terhadap Pertumbuhan dan Organ 
Dalam Tikus Putih Wistar (Rattus norvegicus). Skripsi. Fakultas Perikanan Universitas Brawijaya. Malang: tidak dipublikasikan.

Jawapos. 2009. Gerebek Pabrik Tahu Berformalin.

(Online).

(http://www.jawapost.co.id. Diakses 13 Novemeber 2009).

Karo-karo, Trijaya dan Fit. 2008. Cari Ikan Berfprmalin Petugas BBPOM Diusir.

(Online). (http://autos.okezone.com. Diakses 13 November 2009).

Kartikaningsih, Hartati. 2008. Pengaruh Paparan Berulang Ikan Berformalin Terhadap Kerusakan Hati dan Ginjal Mencit (Mus musculus) Sebagai Media Pembelajaran Keamanan Pangan. Disertasi. PSSJ Pendidikan Biologi Pascasarjana UM. September 2008.

Kholilah, Siti Nur. 2006. Studi Identifikasi Ikan Asin Berformalin di Pasar Kota Malang. Skripsi. Fakultas Perikanan Universitas Brawijaya. Malang: tidak dipublikasikan.

Kompas Cyber Media. Tanpa Tahun. Menatap Tanahair dari Tanah Blair. (online). (http://www.depkes.go.id. Diakses 5 Septemebr 2009).

Kurnia, T.A. 2007. Pengaruh Konsumsi Udang Putih (Penaeus merquensis) Berformalin terhadap Berat Badan dan Histologis Tikus Wistar (Rattus norvegicus). Skripsi. Fakultas Perikanan Universitas Brawijaya. Malang: tidak dipublikasikan.

Linder, Maria C. (edt.). 1992. Biokimia Nutrisi dan Metabolisme. Penerjemah: Aminuddin Parakasi. Jakarta: UI-Press.

Mardiyansyah, Luthfi. 2008. Gizi Buruk di Indonesia. Makalah. SMPN 167 Jakarta.

(Online). (http://rizkisaputro.files.wordpress.c om. Diakses 2Oktober 2009).

Menteri Kesehatan RI. 1999. Permenkes RI No. 1168/MENKES/PER/X/1999 tentang Perubahan Atas Permenkes RI No. 722/MENKES/PER/IX/1988. Departemen Kesehatan RI Jakarta.

Mulia, SM. 2007. Gizi, Masyarakat Berkualitas dan Pencapaian Tujuan MDGs. (online), (http://www.icrponline.org/wmprint.php?ArtLD=518 , diakses 5 September 2009).

Naria, Evi. 2004. Resiko Pemajanan Formaldehid sebagai Bahan Pengawet Tekstil di Lingkungan Kerja. Dizitiged by USU Digital Library. Bagian Kesehatan Lingkungan FKM USU.

Nolodewo, Adi., Yuslam, dan Muyassaroh. 2007. Paparan Formaldehid sebagai Faktor Resiko Kanker Nasofaring: Kajian pada Penderita Karsinoma Nasofaring di RS. Dr. Kariadi Semarang. Cermin Dunia Kedokteran, 155: 96-99.

Pemerintah RI. 1996. UU RI No. 7 Tahun 1996 tentang Pangan. Jakarta: Lembaran Negara RI.

Prijana dan Semendison. 2005. Metode Sampling Terapan untuk Penelitian Sosial. Bandung: Humaniora.

Prijono, Eddy. 2007. Masalah Pemakaian Formalin pada Pangan Ditinjau dari Aspek Hukum Keamanan Pangan. Makalah tidak dipublikasikan. FKG-Unpad Bandung.

Rafif, 2010. Pengolahan dan Pengawetan Bahan Makanan serta Permasalahannya. (online). (http://www.placeschool.com. Diakses 27 Juli 2010). 
Raihan, Cahya Fikry. 2003. Pengaruh Waktu Perendaman terhadap Serapan Formalin dan Proses Deformalinisasi Ikan Asin Jmabal Hasil Proses Penggaraman Kering. Skripsi. Jurusan Kimia FMIPA ITS Surabaya.

Ritchie, Ingrid M. and Lehnen, Robert G. 1987. Formaldehyde-realted Complain of Residents Living in Mobile anda Conventional Homes. American Journal of Public Health, 3(77): 323-328.

Shaham, J., Bomstein, Y., Meltzer, A., Kaufman, Z., Palma, E., and Ribak, J. 1996. DNA-protein Crosslinks, a Biomaker of Exposure to Formaldegyde - in vitro and in vivo Studies. Carcinogenesis, 17(1): 121125.

Sihombing, M. dan Sihombing, G. 1996. Nilai Biologik Tahu yang Direndam dalam Formalin. Cermin Dunia Kedokteran (111): 17-19. (online), (http://www.kalbe.co.id/files/cdk/fil es/08NilaiBiologikTahuyangDirend am111.pdf/08NilaiBiologikTahuyan gDirendam111.html, diakses 7 Agustus 2010).

Supardi, I. dan Sukamto. 1999. Mikrobiologi dalam Pengolahan dan Keamanan Pangan. Bandung: Alumni.

Surabaya Post. 2009. Pabrik Tahu Disegel. (Online). (http://www.surabayapost.co.id. Diakses 13 November 2009).

Taslim, Nurpudji A. 2005. Kontroversi seputar Gizi Buruk: Apakah Ketidakberhasilan Departemen Kesehatan? Makalah. Pusat Pangan, Gizi, dan Kesehatan. Unhas Makasar . (Online). (http://www.gizi.net. Diakses 2 Oktober 2009).
Virdhani, Marieska Harya. 2009. BPOM: 40\% Jajanan Kantin SD Berbahaya bagi Kesehatan. (Online). (http://news.okezone.com. Diakses 13 November 2009).

Widodo dan Rudimah, Siti Yusi. (tanpa tahun). Respon Konsumen terhadap Pemberitaan Ditemukannya Formalin pada Produk Pangan Olahan. Jurusan Sosial Ekonomi Pertanian/Agrobisnis. Faperta UMY, Yogyakarta. (Online). (http://ejournal.unud.ac.id. Diakses 9 Oktober 2009).

Widyaningsih, Tri Dewanti dan Murtini, Erna Sofia. 2006. Alternatif Pengganti Formalin pada Produk Makanan. Surabaya: Trubus Agrisarana.

WHO. 1989. Environmental Health Criteria For Formaldehyde. Published Under The joint Sponsor of The United Nation Environment Program, The International Labour Organization, and The World Health Organization. Geneva: WHO.

Zahra, Tootian., Parviz, Tajik., Simin, Fazelipour., and Mehdi, Taghva. 2007. Effect of Formaldehyde Injection in Mice on Testis Function. International Journal of Pharmacology, 3(5): 421-424. 